\title{
Influence of the formulation type (o/w, w/o/w emulsions and ointment) on the topical delivery of paromomycin
}

\author{
Sérgio Fernandes de Oliveira Gomes, Elzíria de Aguiar Nunan, Lucas Antônio Miranda Ferreira* \\ Department of Pharmaceutics, Faculty of Pharmacy, Federal University of Minas Gerais
}

*Correspondence:

L. A. M. Ferreira

Faculty of Pharmacy

Federal University of Minas Gerais

Av. Antônio Carlos, 6627

31270-901 - Belo Horizonte - MG

E-mail: lucas@farmacia.ufmg.br
Ointments containing paromomycin (PA) have been used for topical treatment of cutaneous leishmaniasis. Although influence of the vehicle on skin permeation is crucial for optimization of formulations containing $P A$, this aspect has not been investigated experimentally. In this study, we have evaluated the influence of the formulation type [oil-in-water (o/w), water-in-oil-in-water $(w / o / w)$ emulsions and ointment] on in vitro release and skin permeation of $P A$ and experiments were carried out on cellulose acetate membrane and skin biopsies from hairless mice, respectively. $P A$ release from o/w emulsion (51.7\% \pm 0.9 of dose applied) was faster than that observed for $w / o / w$ emulsion $(3.0 \% \pm 0.5)$. PA absorption from o/w emulsion $(87.1 \% \pm 3.9)$ through stripped skin was 5 to 6 times higher than that observed for w/o/w multiple emulsion $(14.7 \% \pm 0.5)$ and ointment $(16.6 \% \pm 0.1)$. PA permeation through intact (normal) skin was negligible for all tested formulations. Skin uptake from o/w emulsion $(0.9 \% \pm 0.1)$ was greater than that observed for w/o/w multiple emulsion $(0.3 \% \pm$ $0.1)$ and ointment $(0.1 \% \pm 0.1)$. These results suggest that a hydrophilic vehicle (o/w emulsion) could be an interesting alternative to improve topical delivery of $P A$.

\section{INTRODUCTION}

Tegumentary leishmaniasis is a complex group of diseases caused by various different Leishmania species. Each species is responsible for a certain group of clinical symptoms, which can vary from the presence of single localized ulcers (cutaneous leishmaniasis) to the diffuse or the disfiguring mucocutaneous forms of the disease (Barral-Neto et al., 1995).

Currently, pentavalent antimonials, administered parenterally, are considered the first line drugs in treatment of cutaneous leishmaniasis. This treatment causes a variety of side effects, including changes in the electrocardiogram and increase of hepatic transaminases. Thus, many alternative systemic and topical treatments have been used to treat cutaneous leishmaniasis (Grevelink, Lerner, 1996).

As an alternative treatment, local therapy can be of value because of its simple administration, safety and fewer side effects. Paromomycin sulphate (PA), a aminoglycoside antibiotic, has demonstrated a high in vitro activity against Leishmania major amastigotes in 
macrophages (E1-On, Greenblat, 1983; Neal et al., 1995).

In experimental models and clinical studies, El-On et al. $(1984,1986,1988)$ have been demonstrated that an ointment containing $15 \%$ PA and $12 \%$ methylbenzethonium chloride (MBCL), a quaternary ammonium surfactant, was effective against $L$. major. The local side effects due to $\mathrm{MBCl}$ (Berman, 1997) have led to development of a formulation containing PA and urea as skin penetration enhancer of the drug (Neal et al., 1994). This ointment cured all L. major lesions on Balb/C mice, however clinical trials carried out in Tunisia (Salah et al., 1995) and in Iran (Asilian et al., 1995) suggest that this formulation was not as effective as that containing $\mathrm{PA} / \mathrm{MBCl}$. The modification of the vehicle (base) could be also an alternative approach to enhance the anti-leishmanial activity of PA.

Although it is well established that the vehicle greatly influences drug percutaneous absorption, this aspect has not been experimentally investigated for the topical application of PA. The vehicle can influence drug absorption both by changing the stratum corneum permeability or the thermodynamic activity of the drug (Moser et al., 2001; Lalor, Flynn, Weiner, 1994, 1995). Thus, the aim of this study was to investigate, by the first time, the influence of the vehicle on in vitro release and skin permeation of PA from emulsions and an ointment.

Since the cutaneous leishmaniasis lesions often develop into an ulcer without stratum corneum (Grevelink, Lerner, 1996; Neal et al., 1994), the principal barrier for skin penetration, a vehicle-controlled delivery system (w/o/w multiple emulsion) containing PA was also developed. The skin permeation and release of glucose, as hydrophilic drug model, from w/o/w emulsion was prolonged when compared with that obtained with an o/w emulsion (Ferreira et al., 1995). Thus, the three preparations (o/w and w/o/w emulsions and ointment) were compared.

\section{MATERIAL AND METHODS}

\section{Material}

Paromomycin sulfate (PA), potency of $718 \mathrm{mg} / \mathrm{g}$, was donated by Pharmacia \& Upjohn (Milan, Italy). The surfactants used were: a silicone-based polymeric lipophilic surfactant $\left(\right.$ Abil EM90 ${ }^{\circledR} ; \mathrm{HLB}=3$ ) obtained from Goldschmidt (France) and a hydrophilic surfactant, a block copolymer of ethylene and propylene oxide (Synperonic $\mathrm{PEF} / 127^{\circledR}$; HLB $=18-23$ ) donated by ICI Surfactants (Belgium). Paraffin oil and soft white paraffin were obtained from Favab (Brazil). All other chemicals used were analytical reagent grade.

\section{Methods}

\section{Preparation of the formulations}

In order to investigate only the influence of the emulsion type, w/o/w multiple and o/w simple emulsions were prepared according to the same formula. It was similar to that described previously (Ferreira et al., 1994, 1995): $22 \%$ of paraffin oil, $3 \%$ of lipophilic surfactant, $1 \%$ of hydrophilic surfactant, $1 \%$ of paromomycin sulfate (PA) and $73 \%$ of $0.08 \mathrm{M} \mathrm{NaCl}$, by weight. However, procedures of emulsification were different.

$\mathrm{W} / \mathrm{o} / \mathrm{w}$ multiple emulsion was prepared by a twostage emulsification procedure. In the first step, a w/o primary emulsion was formed by adding the aqueous phase to oily phase at $8,000 \mathrm{rpm}$ for 30 minutes. Emulsification was carried out using a ULTRA TURRAX T-25 type agitator (IKA, Staufen, Germany). In a second step, w/o primary emulsion was dispersed to external aqueous phase using an EUROSTAR basic agitator (IKA, Staufen, Germany) at $400 \mathrm{rpm}$ for 15 minutes (Table I).

$\mathrm{O} / \mathrm{w}$ emulsion was prepared through the addition of the aqueous phase to oily phase at $8,000 \mathrm{rpm}$ for 15

TABLE I - Composition ( $\% \mathrm{w} / \mathrm{w})$ of the $\mathrm{w} / \mathrm{o} / \mathrm{w}$ multiple emulsion

\begin{tabular}{cclc}
\hline Steps & Phase & Components & \% w/w \\
\hline First & Oily & Oil $^{\text {a }}$ & 30 \\
w/o emulsion & & Hydrophobic surfactant & 4 \\
& inner aqueous & NaCl 0.08M & 64.7 \\
Second & & Paromomycin & 1.3 \\
w/o/w emulsion & external aqueous & w/o emulsion & 75 \\
\hline
\end{tabular}

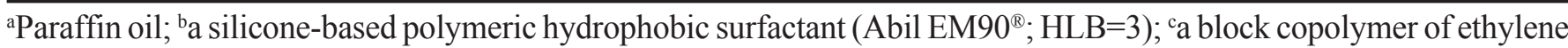
and propylene oxide (Synperonic PEF $/ 127^{\circledR}$; HLB=18-23). 
minutes. Emulsification was carried out using an ULTRA TURRAX T-25® agitator at $25^{\circ} \mathrm{C}$. Ointment was prepared by triturating PA into soft white paraffin until a homogeneous mixture has been obtained.

\section{Characterization of the emulsions}

After preparation, microscopic observations (Olympus-Micronal, Brazil) and conductivity values (Conductivity Meter Micronal B-330, Brazil) confirmed that two emulsion types (w/o/w or o/w) were obtained.

Percentage of PA entrapped in internal phase of the w/o/w emulsion was determined through the difference between total and encapsulated PA content. To determine total PA content, samples of $100 \mathrm{mg}$ of the multiple emulsions were diluted with $100 \mathrm{~mL}$ of distilled water and extracted with three 40-mL quantities of chloroform. Chloroform was discarded and PA concentration in aqueous solution was determined by microbiologic assay (see below). Not encapsulated PA content was determined after dilution of samples $(100 \mathrm{mg})$ in $25 \mathrm{~mL}$ of an aqueous solution of glucose at same osmolarity as that of the internal aqueous phase. Aliquots were filtered through Millipore filter $(0.45 \mathrm{~mm})$ and PA concentration was determined by microbiologic assay.

\section{In vitro release of $P A$}

In vitro release of $\mathrm{PA}$ was determined in modified Franz diffusion cells, as described previously (Ferreira et al., 1995). Briefly, cellulose acetate membranes (thickness: $25 \pm 1 \mathrm{~mm}$; MWC 5.000; Dianorm - Munique) were placed horizontally dividing the cell in two compartments: the donor and the receptor. Receptor compartment was filled with $0.05 \mathrm{M}$ phosphate buffered ( $\mathrm{pH}$ 7.4) saline. This receptor liquid, maintained at $37{ }^{\circ} \mathrm{C}$, was continually stirred with a small magnetic bar.

These experiments were carried out in infinite dose and the donor compartment was covered with Parafilm ${ }^{\circledR}$ (American National Can, Greenwich, CT). Preparations were applied $(500 \mathrm{mg}$ ) and serial sampling was performed at specific times by totally removing receptor fluid and refilling with fresh solution. PA concentration was determined by microbiologic assay (see below).

\section{In vitro skin permeation}

In vitro skin permeation through dorsal skin excised from hairless mice was determined with the same Franz cells described above. Male, 8 weeks old hairless mice (strain HRS/J Jackson Laboratories, Bar Harbor, ME) were sacrificed by cervical rupture and the dorsal skin was used immediately. These experiments were made in the presence or absence of the stratum corneum (SC). SC was removed by stripping 5 times with a cellophane tape (SCOTH Magic ${ }^{\circ} 810,3 \mathrm{M}$ ). Receptor compartment was filled with $0.05 \mathrm{M}$ phosphate buffered saline ( $\mathrm{pH} 7.4)$.

Donor compartment was left open and preparations (50 mg), containing $1 \% \mathrm{w} / \mathrm{w}$ of PA, were applied on the skin and spread with a glass rod. Serial sampling was performed as described above.

At the end of the experiments, removal of the excess formulation was determined by washing and rinsing of the treated surface twice times with $500 \mu \mathrm{L}$ of liquid cleansing soap at $5 \%$ (Extrán ${ }^{\circledR}$, Merk) and twice times with $500 \mu \mathrm{L}$ of water, removing the residue with a cotton swab. Washing solvent, pipette tips and cotton swab were added to a bottle containing $100 \mathrm{~mL}$ of distilled water. PA concentration in this solution was determinated by microbiologic assay. Thus, recovery from ointment was of $95.5 \% \pm 2.2$ of the dose applied. PA remaining into skin (dermis + epidermis) was extracted as follows: skin biopsies were vortex-mixed for 15 minutes in distilled water $(2 \mathrm{~mL})$; samples were centrifuged and supernatant fractions were filtered through Millipore filter $(0.45 \mathrm{~mm})$. PA concentration was determined by microbiologic assay. Formulations without PA were also submitted to all protocols described previously. These samples did not interfered with the analysis method.

\section{Microbiologic assay of the PA}

Microbiological assays are traditionally used for determination of aminoglycoside antibiotics. Assay of PA was made according methodology described in United States Pharmacopoeia (USP 23, 1995). Briefly, concentration of PA was determined by an agar-diffusion inhibition assay of the growth of a test organism, Staphylococcus epidermidis (ATCC 12,228). Diffusion of PA in agar resulted in an inhibition halo that represented the absence of growth of the microorganism. A linear relationship between diameter of the inhibition halo and logarithm of the PA concentration was observed. PA concentration was determined from a standard curve $\left(y=9.9417 x+8.5568 ; R^{2}=0.9988\right)$.

\section{Statistical Analysis}

Analysis of variance (ANOVA) was used to evaluate differences between means. Differences at level pd"0.05 were considered significant.

\section{RESULTS AND DISCUSSION}

The aim of this study was to evaluate the influence of the vehicle on topical delivery of PA. Therefore, 
membrane of cellulose acetate was used only as a preliminary step to studies that will include in vitro skin permeation. This synthetic membrane has been used as in vitro release method for creams, ointments and gels based on the principle that the effectiveness of topical products is dependent on the release of active drug from its dosage form (Shah, Skelly, 1993).

Release of PA from o/w simple emulsion $(51.7 \% \pm$ 0.9 of the applied dose) was considerably greater than that observed from $\mathrm{w} / \mathrm{o} / \mathrm{w}$ multiple emulsion $(3.0 \% \pm 0.5)$. When half of the amount of PA was added to external aqueous phase of the $\mathrm{w} / \mathrm{o} / \mathrm{w}$ multiple emulsion $\left(\mathrm{w} / \mathrm{o} / \mathrm{w}_{\mathrm{PA}}\right)$, released amount was intermediary $(26.2 \% \pm 0.4)$ in comparison with other preparations (Figure 1).

High release from $\mathrm{o} / \mathrm{w}$ emulsion can be attributed to availability of PA in aqueous phase of this emulsion. Lalor, Flynn, Weiner $(1994,1995)$ showed that, in an emulsion, interaction of the drug between water and oil phase can determine extent of lowering of the thermodynamic activity in external phase which is in contact with membrane. Partitioning of PA into internal oily phase or its micelar solubilization in external phase of the $\mathrm{o} / \mathrm{w}$ emulsion is unlikely, due to hydrophilic characteristic of the drug.

The extremely slow release of PA from the multiple emulsion can be explained by the fact that diffusion of PA through oily phase is the limiting step for drug release.
Percentage of PA entrapped in internal aqueous phase of the $\mathrm{W} / \mathrm{O} / \mathrm{W}$ emulsion was high $(91.3 \%)$, whereas the PA percentage in external aqueous phase was low (8.7\%). Only this content of PA in external phase would be immediately available for release. A similar phenomenon has been observed for glucose from multiple emulsion (Ferreira et al., 1995). This hypothesis is also supported by the fact that PA release from $\mathrm{w} / \mathrm{o} / \mathrm{w}_{\mathrm{PA}}$ was greater than that observed from $\mathrm{w} / \mathrm{o} / \mathrm{w}$ multiple emulsion, once that a larger amount of drug is available in external phase.

In order to validate PA recovery from surface of the skin, previous experiments, performed immediately after the application of the preparations, were conducted. The data showed that PA recovery from $\mathrm{o} / \mathrm{w}, \mathrm{w} / \mathrm{o} / \mathrm{w}$ emulsions and ointment was of $95.1 \% \pm 2.5,92.9 \% \pm 1.8$ and $62.8 \%$ $\pm 1.1(\mathrm{n}=3)$, respectively. In order to improve PA recovery rate from lipophillic ointment, a first washing was performed with $500 \mu \mathrm{L}$ of chloroform and then as described for the other formulations (Extran ${ }^{\hat{a}}$ and water). Skin uptake and permeation data of PA from emulsions and ointment through stripped skin are redrawn in Table II and Figure 2, respectively. Mass balance ranged from 92 to $98 \%$. Skin permeation of PA from o/w emulsion $(87.1 \%$ \pm 3.9 ) was 5 times higher than that observed for $\mathrm{w} / \mathrm{o} / \mathrm{w}$ multiple emulsion $(14.7 \% \pm 0.5)$ and ointment $(16.6 \% \pm$ $0.1)$. Greater efficacy of the $\mathrm{o} / \mathrm{w}$ emulsion for delivering

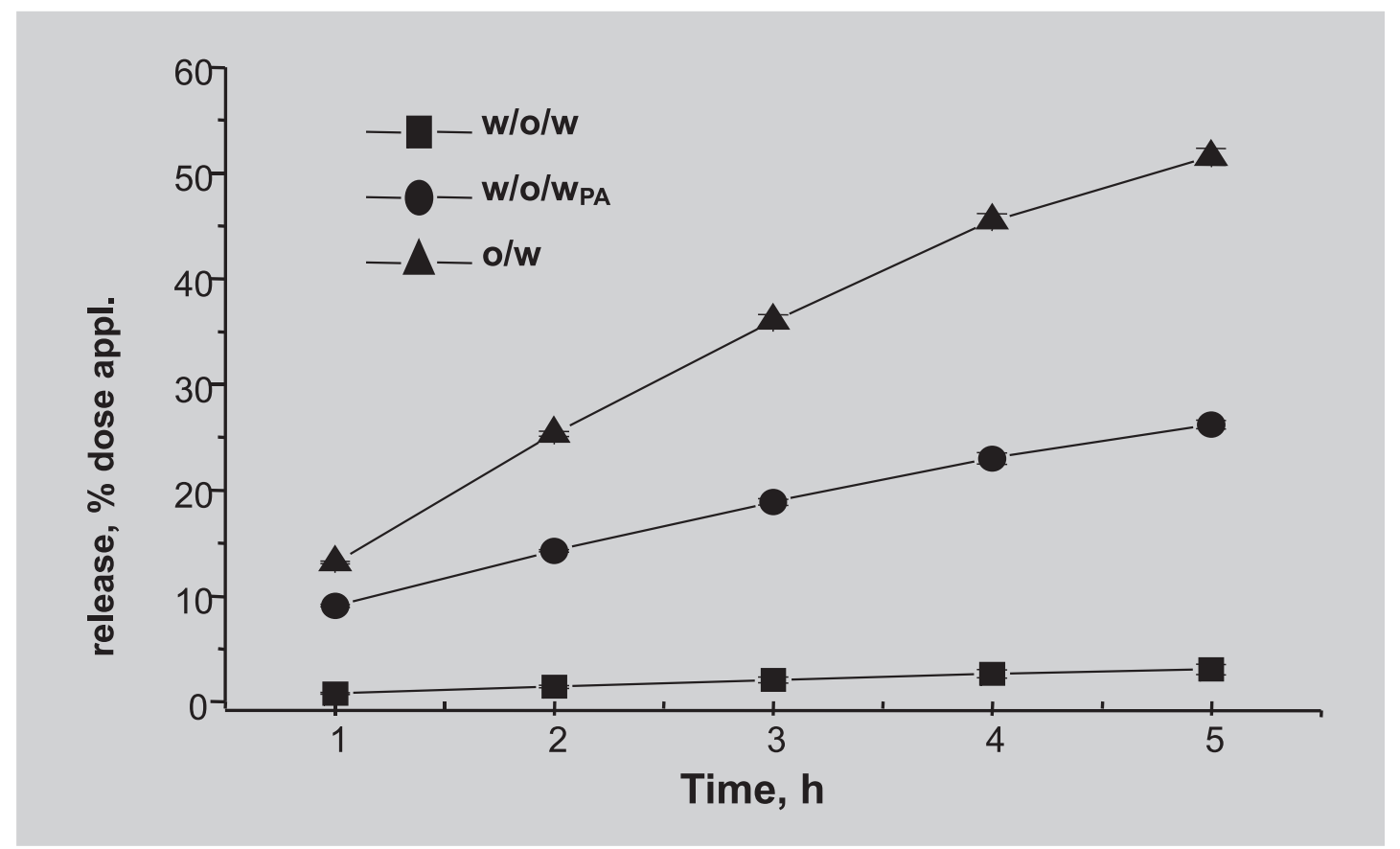

FIGURE 1 - In vitro release of PA from o/w, w/o/w and w/o/ $\mathrm{w}_{\mathrm{PA}}$ emulsions across cellulose acetate membrane. The $\mathrm{W} / \mathrm{o} / \mathrm{w}_{\mathrm{PA}}$ multiple emulsion contains half of the PA amount into external aqueous phase. The formulations containing $1 \%$ w/w of PA were applied (500 mg-infinite dose) over synthetic membranes mounted in Franz cells. The expressed values correspond to the mean value $\pm \mathrm{SD}(\mathrm{n}=3)$. 


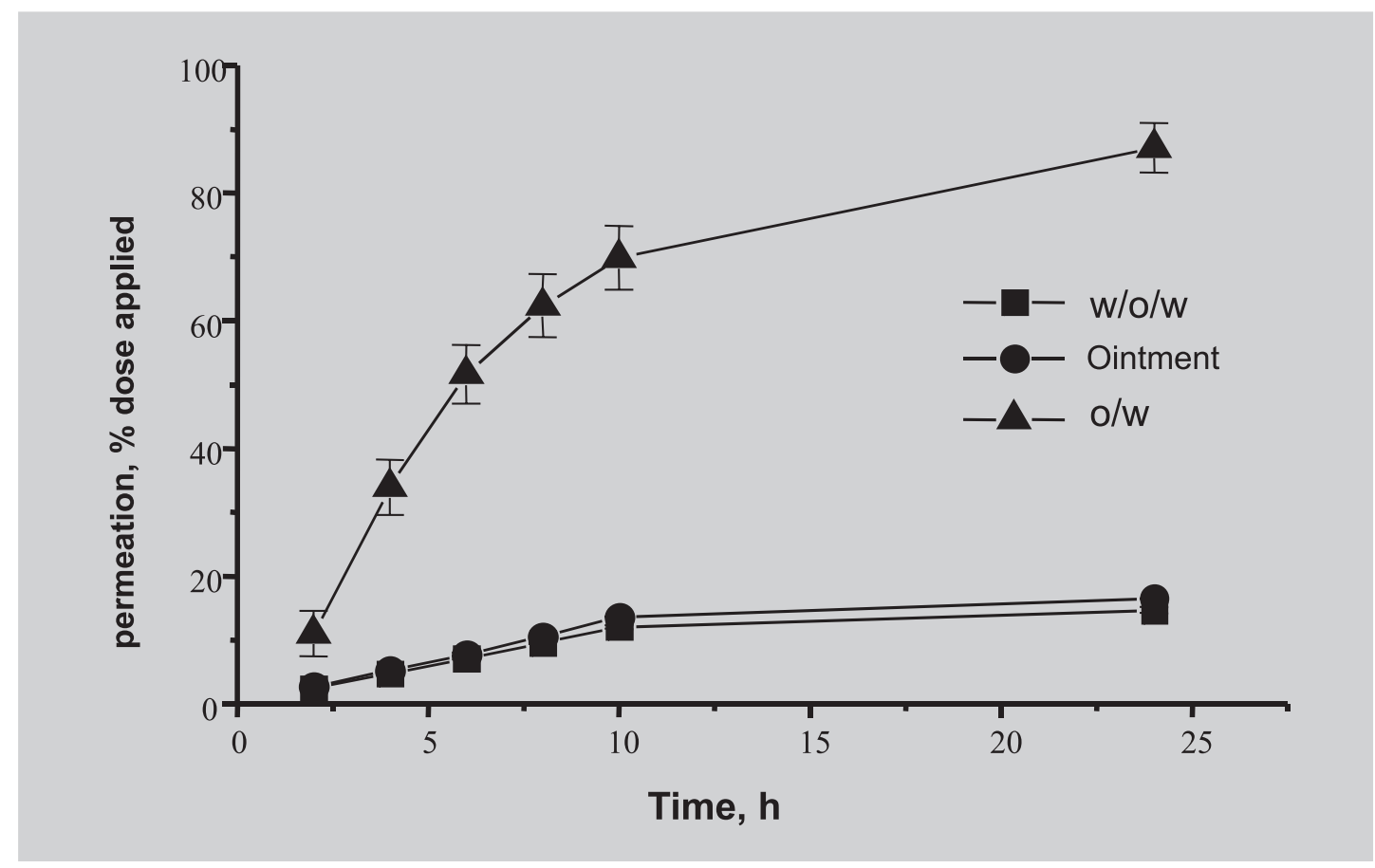

FIGURE 2 - In vitro skin permeation of PA from o/w, w/o/w emulsions and ointment through dorsal skin excised from hairless mice in partial absence of stratum corneum. The formulations containing $1 \% \mathrm{w} / \mathrm{w}$ of PA were applied $(50 \mathrm{mg}$ finite dose) over skin biopsies mounted in Franz cells. Each point represents average ( $n=3) \pm$ SD.

PA might be due to higher concentration of the drug in external phase and/or to rapid increase in thermodynamic activity due to evaporation of water. Changes in thermodynamic activity of the drug, through evaporation of a volatile vehicle, can often be a significant factor in topical delivery (Chiang et al., 1989; Tata, Flynn, Weiner, 1995).

There is a good correlation between the permeation and release data for the o/w emulsion and multiple emulsion. Therefore, release and skin permeation of PA from $\mathrm{o} / \mathrm{w}$ emulsion were higher than those observed for multiple emulsion, despite of differences in experimental protocols (infinite and finite dose).

An analysis of Figure 2 demonstrates that flux of PA from $\mathrm{w} / \mathrm{o} / \mathrm{w}$ emulsion and ointment already declines when only 14 to $16 \%$ of the applied dose has been permeated.
For the multiple emulsion, this phenomenon could be attributed to depletion of PA in the external aqueous phase. For the ointment, this can be explained by permeation of a small fraction of PA which was initially solubilized in this preparation. These results suggest that the release of a small fraction of PA from both formulations was associated to a low skin penetration.

Since the skin permeation was greater from o/w emulsion in comparison with other preparations, a higher concentration of PA into skin could be expected. However, surprisingly, PA uptake into stripped skin from o/w emulsion was lower than that observed for w/o/w emulsion (Table II). This can be explained by high depletion of the PA concentration in donor compartment, once $87 \%$ of the applied dose have been permeated from o/w emulsion after 24 hours.

TABLE II - Distribution ${ }^{\mathrm{a}}$ of PA (\% dose applied), into stripped skin, after $24 \mathrm{hr}$

\begin{tabular}{lcccc}
\hline Formulations & Permeation & Skin $^{\mathbf{b}}$ & Surface wash & Total recovery(\%) \\
\hline o/w emulsion & $87.1 \pm 3.9$ & $1.1 \pm 0.1$ & $9.6 \pm 1.7$ & 97.9 \\
w/o/w emulsion & $14.7 \pm 0.5$ & $1.7 \pm 0.2$ & $75.2 \pm 1.9$ & 91.5 \\
Ointment & $16.6 \pm 0.1$ & $0.9 \pm 0.1$ & $74.3 \pm 2.7$ & 91.7 \\
\hline
\end{tabular}

${ }^{a}$ formulations containing $1 \% \mathrm{w} / \mathrm{w}$ of PA were applied (50 mg-finite dose) over stripped skin biopsies from hairless mice

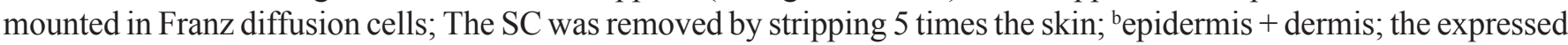
values correspond to the mean value $\pm \operatorname{SD}(n=3)$. 
TABLE III - Distribution ${ }^{\mathrm{a}}$ of PA (\% dose applied), into normal skin, $24 \mathrm{hr}$ after application of the formulations

\begin{tabular}{lcccc}
\hline Formulations & Permeation & Skin $^{\mathbf{b}}$ & Surface wash & Total recovery(\%) \\
\hline o/w emulsion & ND $^{\mathrm{c}}$ & $0.9 \pm 0.1$ & $99.5 \pm 2.6$ & 100.4 \\
w/o/w emulsion & $\mathrm{ND}$ & $0.3 \pm 0.1$ & $91.0 \pm 1.7$ & 91.3 \\
Ointment & $\mathrm{ND}$ & $0.1 \pm 0.1$ & $98.5 \pm 7.7$ & 99.1 \\
\hline
\end{tabular}

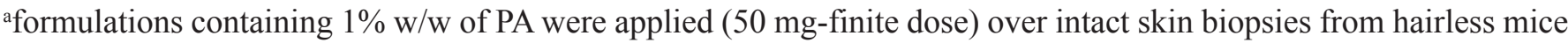
mounted in Franz diffusion cells; ${ }^{b}$ epidermis + dermis; ${ }^{\circ}$ no detected.

The expressed values correspond to the mean value $\pm \mathrm{SD}(\mathrm{n}=3)$.

Skin uptake and permeation of PA through intact skin from tested preparations are redrawn in Table III. The mass balance ranged from 91 to $100 \%$. PA permeation was not detectable and below of detection limit. As expected, PA permeation through stripped skin was higher than that observed for intact skin. PA uptake into intact skin from o/ $\mathrm{w}$ emulsion $(0.9 \% \pm 0.1)$ was about 3 and 10 times higher than that observed for $\mathrm{w} / \mathrm{o} / \mathrm{w}$ multiple emulsion $(0.3 \% \pm 0.1)$ and ointment $(0.1 \% \pm 0.1)$, respectively (Table III). Improved topical delivery of PA from o/w emulsion can be attributed to thermodynamic activity higher than that observed for other formulations, as discussed earlier. Total deposition (skin uptake) and skin permeation of lactic acid into or through porcine skin, determined using a finite dose, was in the following order: $\mathrm{o} / \mathrm{w}>\mathrm{w} / \mathrm{o} / \mathrm{w}>\mathrm{w} / \mathrm{o}$ emulsions (Sah, Mukherjee, Wickett, 1998).

Although it has not been possible to evaluate skin permeation of PA through the intact skin, our studies conducted with stripped skin, a model that may be closer to what is observed in cutaneous leishmaniasis, showed significant differences among formulations. Our findings are in good agreement with those previously reported (Stone et al., 1968), in which the percutaneous absorption of gentamycin, an antibiotic structurally related to PA, from water-miscible bases was greater and faster than from ointment bases.

In conclusion, release of PA from o/w emulsion was faster than from $\mathrm{w} / \mathrm{o} / \mathrm{w}$ emulsion. PA release from $\mathrm{w} / \mathrm{o} / \mathrm{w}_{\mathrm{PA}}$ multiple emulsion containing half of the PA amount in the external aqueous phase was intermediate. Skin uptake and permeation of $\mathrm{PA}$ from $\mathrm{o} / \mathrm{w}$ emulsion were higher than those observed for w/o/w emulsion and ointment. An important consideration in cutaneous leishmaniasis is the skin condition. Topical formulations may be applied either to open lesions that have lost SC barrier property or to thickened lesions that represent an additional barrier to absorption (Garnier, Croft, 2002). Thus, our findings suggest that a hydrophilic vehicle ( $\mathrm{o} / \mathrm{w}$ emulsion) could be an interesting alternative to improved topical delivery of PA in both conditions. Additional studies are required to evaluate the influence of skin permeation enhancers incorporated in this vehicle.

\section{ACKNOWLEDGEMENTS}

The authors thank Fundação de Amparo à Pesquisa do Estado de Minas Gerais - FAPEMIG (MGBrazil). We are gratefull to Dr. G. L. Devani from PHARMACIA \& UPJOHN (Italy) for donating samples of paromomycin sulfate.

\section{RESUMO}

\section{Influência da forma farmacêutica (emulsão múlti- pla A/O/A, emulsão O/A e pomada) sobre a permeação e retenção cutânea da paromomicina}

Pomadas contendo paromomicina (PA) são utilizadas no tratamento tópico da leishmaniose cutânea. Embora a influência do veículo seja crucial para otimização de formulações contendo PA, este aspecto não tem sido investigado experimentalmente. Neste estudo, nós avaliamos a influência do tipo de formulação [emulsões óleo-em-água (o/a), múltipla água-em-óleo-em-água (a/o/a) e pomadas] sobre a liberação e permeação cutânea in vitro da PA e os experimentos foram conduzidos sobre membranas de acetato de celulose $e$ biópsias de pele de camundongos glabros, respectivamente. A liberação de PA a partir da emulsão o/a (51,7\% da dose aplicada) foi mais rápida do que aquela observada a partir da emulsão múltipla a/o/a (3,0\% da dose aplicada). A permeação cutânea da PA a partir da emulsão o/a $(87,1 \% \pm 3,9)$, através da pele sem estrato córneo, foi 5 a 6 vezes mais alta do que aquela observada para a emulsão múltipla a/o/a $(14,7 \% \pm 0,5)$ e pomada $(16,6 \% \pm 0.1)$, respectivamente. A permeação da PA através da pele normal foi desprezivel para todas as formulações avaliadas. Nesta condição, a retenção cutânea a partir da emulsão o/a $(0,9 \% \pm 0,1)$ foi maior do que aquela 
observada para a emulsão múltipla $(0,3 \% \pm 0.1)$ e pomada. Esses resultados sugerem que um veículo hidrofilico seria uma alternativa interessante para aumentar o transporte e a permeação cutânea da PA.

UNITERMOS: Paromomicina. Permeação cutânea. Emulsões. Pomadas. Leishmaniose cutânea.

\section{REFERENCES}

ASILIAN, A.; JALAYER, T.; WHITWORTH, J.A.G.; GHASEMI R.L.; NILFOROOSHZADEH, M.; OLLIARO, P. A randomized, placebo-controlled trial of a two-week regimen of aminosidine (paromomycin) ointment for treatment of cutaneous leishmaniasis in Iran. Am. J. Trop. Med. Hyg., Lawrence, v.53, p.648-651, 1995.

BARRAL-NETO, M.; MACHADO, P.; BARRAL, A. Human cutaneous leishmaniasis: recent advances in physiopathology and treatment. Eur. J. Derm., Montrouge, v.5, p.104-13, 1995.

BERMAN, J.D. Human Leishmaniasis: clinical, diagnostic and chemotherapeutic developments in the last 10 years. Clin. Infect. Dis., Chicago, v.24, p.684-703, 1997.

CHIANG, C.M.; FLYNN, G.L.; WEINER N.D.; SZPUNAR, G.J. Bioavailability assessment of topical delivery systems: effect of vehicle evaporation upon in vitro delivery of minoxidil from solution formulations. Int J. Pharm., Amsterdam, v.55, p.229-236, 1989.

EL-ON, J.; GREENBLATT, C.L. An in vitro model for testing the effect of anti-leishmanial drugs of possible use in topical treatment. Curr. Ther. Res., New York, v.33, p.660-669, 1983.

EL-ON, J.; JACOBS, G.P.; WITZTUM, E.; GREENBLATT, C.L. Development of topical treatment for cutaneous leishmaniasis caused by Leishmania major in experimental animals. Antimicrob. Agents Chem., Washington, v.26, p.745-751, 1984.

EL-ON, J.; LIVSHIN, R.; EVEN-PAZ, Z.; HAMBURGER, D.; WEINRAUCH, L. Topical treatment of cutaneous leishmaniasis. J. Invest. Dermatol., New York, v.87, p.284-288, 1986.

EL-ON, J.; JACOBS, G.P.; WEINRAUCH, L. Topical chemotherapy of cutaneous leishmaniasis. Parasitol. Today, Amsterdam, v.4, p.76-81, 1988.
FERREIRA, L.A.M.; SEILLER, M.; GROSSIORD, J.L.; MARTY, J.P.; WEPIERRE J. Vehicle influence on in vitro release of metronidazole: Role of w/o/w multiple emulsion. Int. J. Pharm., Amsterdam, v.109, p.251-259, 1994.

FERREIRA, L.A.M.; SEILLER, M.; GROSSIORD, J.L.; MARTY, J.P.; WEPIERRE J. Vehicle influence on in vitro release of glucose: w/o, w/o/w and o/w systems compared. J. Control. Release, Amsterdam, v.33, p.349$356,1995$.

GARNIER, T.; CROFT, S.L. Topical treatment for cutaneous leishmaniasis. Curr. Opin. Investig. Drugs, London, v.3, p.538-544, 2002.

GREVELINK, S.A.; LERNER, E.A. Leishmaniasis. J. Am. Acad. Dermatol., St. Louis, v.34, p.257-272, 1996.

LALOR, C.B.; FLYNN, G.L.; WEINER, N. Formulation factors affecting release of drug from topical formulations. 1. Effect of emulsion type upon in vitro delivery of ehtyl p-aminobenzoate. J. Pharm. Sci., Washington, v.83, p.1525-1528, 1994.

LALOR, C.B.; FLYNN, G.L.; WEINER, N. Formulation factors affecting release of drug from topical formulations. II. Effect of solubility on in vitro delivery of a series of nalkyl p-aminobenzoates. J. Pharm. Sci., Washington, v.84, p.673-676, 1995.

MOSER, K.; KRIWET, K.; NAIK, A.; KALIA, Y.N.; GUY R.H. Passive skin penetration enhancement and its quantification in vitro. Eur. J. Pharm. Biopharm., Stuttgart, v.52, p.103-112, 2001.

NEAL, R.A.; ALLEN, S.; COY, N.M.; OLLIARO, P.; CROFT, S.L. The sensitivity of leishmania species to aminosidine. J. Antimicrob. Chemother., London, v.35, p.577-584, 1995.

NEAL, R.A.; MURPHY, A.G.; OLLIARO, P.; CROFT, S.L. Aminosidine ointments for the treatment experimental cutaneous leishmaniasis. Trans. R. Soc. Trop. Med. Hyg., London, v.88, p.223-225, 1994.

TATA, S.; FLYNN, G.L.; WEINER, N.D. Penetration of minoxidil from ethanol/propylene glycol solutions: effect of application volume and oclusion. J. Pharm. Sci., Washington, v.84, p.688-691, 1995. 
SAH, A.; MUKHERJEE, S.; WICKETT, R.R. An in vitro study of the effects of formulation variables and product structure on skin permeation of lactic acid. J Cosmet. Sci., v.49, p.257-273, 1998.

SALAH, A.B.; ZAKRAOUI, H.; ZAATOUR, A.; FTAITI, A.; ZAAFOURI, B.; GARRAOUI, A.; OLLIARO, P.L.; DELLAGI, K.; ISMAIL, R.B. A randomized, placebo-controlled trial in Tunisia treating cutaneous leishmaniasis with paromomycin ointment. Am. J. Trop. Med. Hyg., Lawrence, v.53, p.162-166, 1995.

SHAH, V.P.; SKELLY, J.P. Practical considerations in developing a quality control (in vitro release) procedure for topical drug products. In: SHAH V.P., MAIBACH H.I., eds. Topical drug bioavailability, bioequivalence and penetration. New York: Plenum Press, 1993. p. 107116.
STONE, H.H.; KOLB, L.D.; PETTIT, J.; SMITH R.B. The systemic absorption of antibiotic from the burned wound surface. Am. Surg., Atlanta, v.34, p.639, 1968.

UNITED States pharmacopeia. 23.ed. Rockville: United States Pharmacopeial Convention. 1995. p.1690-1696.

Recebido para publicação em 19 de maio de 2003. Aceito para publicação em 05 de abril de 2004. 